\title{
Fair Skin
}

National Cancer Institute

\section{Source}

National Cancer Institute. Fair Skin. NCI Thesaurus. Code C115220.

A human skin color characterized by low levels of eumelanin. 